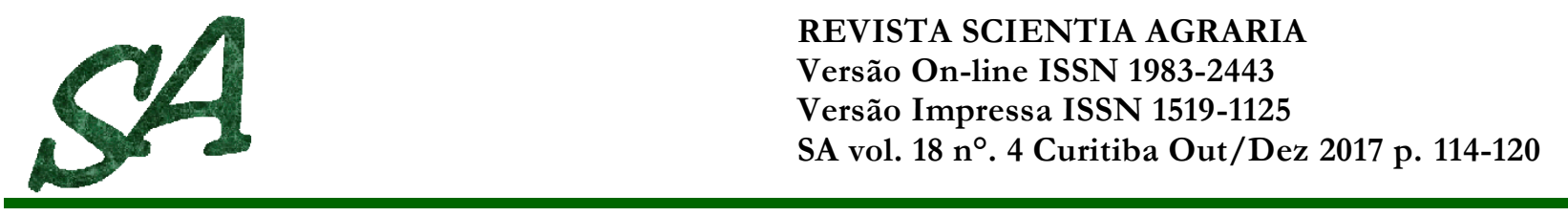

\title{
INITIAL DEVELOPMENT OF EUCALYPTUS CLONE I144 (EUCALYPTUS GRANDIS X EUCALYPTUS UROPHYLLA) IN RESPONSE TO FOLIAR AND SOIL FERTILIZATION
}

\author{
Desenvolvimento inicial de eucalipto clone $I 144$ (Eucalyptus grandis x Eucalyptus urophylla) em resposta à fertilização \\ foliar e de solo
}

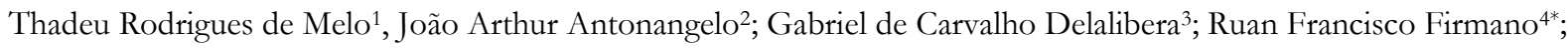
Gustavo Adolfo de Freitas Fregonezi ${ }^{5}$; Renan Ribeiro Barzan ${ }^{1}$
${ }^{1} \mathrm{PhD}$ candidate; Agronomy Department, Londrina State University, Londrina, Paraná, Brazil - thadeurodrigues@hotmail.com; renan_barzan@hotmail.com.
${ }^{2} \mathrm{PhD}$ candidate; Plant and Soil Sciences Department, Oklahoma State University, Stillwater, OK, United States; antonan@ostatemail.okstate.edu
${ }^{3}$ Agronomic Engineer; Agronomy Department, Londrina State University, Londrina, Paraná, Brazil; gabriel.carvalho1505@gmail.com
4* PhD candidate; Soil Science Department, University of São Paulo, Piracicaba, São Paulo, Brazil; ruanff@usp.br *Corresponding author
5Professor; Philadelphia University Center, Londrina, Paraná, Brazil; gustavofregonezi@yahoo.com.br

Artigo enviado em 12/08/2017, aceito em 11/09/2017 e publicado em 20/12/2017.

\begin{abstract}
The nutritional management of eucalyptus (Eucalyptus spp.) is one of the main factors responsible for the success of its cultivation. We aimed to evaluate the initial growth and nutritional status of eucalyptus clone I144 (Eucalyptus grandis $\mathrm{x}$ Eucalyptus urophylla) submitted to foliar fertilizers application containing boron-B, iron-Fe and bio-stimulant and via soil application of nitrogen- $\mathrm{N}$ and phosphorus-P doses. The experiment has been conducted in a rural private property of Tamarana, Parana (PR) in a subdivided plots experiment design with four replications $(\mathrm{n}=4)$. The plots treatments were boron, boron+iron, boron+iron+bio-stimulant applications under algae (Ecklonia maxima) presence and a control (water). The subplots treatments were composed by the application of 100,150 and $250 \mathrm{~g}$ plant $^{-1}$ rates of $10-20-00\left(\mathrm{~N}-\mathrm{P}_{2} \mathrm{O}_{5}-\mathrm{K}_{2} \mathrm{O}\right)$ and a control $\left(0 \mathrm{~g}\right.$ plant ${ }^{-1}$ of $\left.10-20-00\right)$. It was evaluated the height and diameters of plants at 45, 78,117, 150 and 235 days after planting (DAP) and the leaves nutrient content (N, potassium- $\mathrm{K}$, calcium- $\mathrm{Ca}$, magnesium- $\mathrm{Mg}$, sulfur- $\mathrm{S}$, copper- $\mathrm{Cu}$, zinc- $\mathrm{Zn}$, manganese- $\mathrm{Mn}$ and $\mathrm{Fe}$ ) at the end of the cultivation. The fertilization via soil did not interfere on either growth or macronutrients contents. On the other hand, the combined application of foliar fertilizers has increased the macronutrients contents without interfering on growth parameters.
\end{abstract}

Keywords - Eucalyptus, fertilization, growth, nutrition.

Resumo: O manejo nutricional do eucalipto (Eucalyptus spp.) é um dos fatores preponderantes para o sucesso no cultivo. Objetivou-se avaliar o crescimento inicial e o estado nutricional do clone de eucalipto I144 (Eucalyptus grandis $\mathrm{x}$ Eucalyptus urophylla) submetido à aplicação de fertilizantes foliares contendo boro-B, ferro-Fe e bioestimulante e à aplicação de doses de nitrogênio-N e fósforo-P via solo. O experimento foi conduzido em propriedade rural de Tamarana-PR, num delineamento em parcelas subdivididas com quatro repetições. Os tratamentos em nível de parcela foram: aplicação de boro, boro+ferro, boro+ferro+bioestimulante a base de alga (Ecklonia maxima) e controle (água). Em nível de subparcela, aplicaram-se as doses de 100, 150 e 250 g planta $^{-1}$ do formulado 10-20-00 $\left(\mathrm{N}-\mathrm{P}_{2} \mathrm{O}_{5}-\mathrm{K}_{2} \mathrm{O}\right)$ via solo, mantendo-se um tratamento controle (sem aplicação). Avaliaram-se a altura e o diâmetro das plantas aos 45, 78, 117, 150 e 235 dias após o plantio e os teores nutricionais foliares (N, potássio-K, cálcio-Ca, magnésio-Mg, enxofre-S, cobre-Cu, zinco-Zn, manganês-Mn e ferro-Fe) ao final do cultivo. A adubação via solo não influenciou o crescimento ou o teor de nutrientes, enquanto a aplicação dos fertilizantes foliares, principalmente combinados, aumentou os teores dos macronutrientes sem afetar os parâmetros de crescimento.

Palavras-Chave - Eucalyptus, Adubação, crescimento, nutrição. 


\section{INTRODUCTION}

In the last few years, the many technological improvements such as genetical improvement, clone multiplying techniques, mechanization and quality control of forest operations have been promoted substantial gains in productivity. However, mineral nutrition of eucalyptus (Eucalyptus spp.) is commonly not taken into consideration. It can jeopardize the faster growth and higher productivity that could be reach by the specie as long as it requires a significant amount of nutrients (PINTO et al., 2011). Thus, the increase in the productivity effectiveness, as required by the wood industry, will only be reached if an adequate amount of nutrients is supplied to the forest.

The nutrients availability may change the growth rate and the distribution of dry mass thus interfering on the leaf area index and leaves nutrient contents of forest species. Despite the efficiency of clone I144 (Eucalyptus grandis x Eucalyptus urophylla) in the uptake and use of macronutrients (PINTO et al., 2011), it is necessary an adequate nutritional status of plant to express its genetical potential and reach high levels of productivity. Sgarbi et al. (1999), studying a hybrid clone E. grandis x E. urophylla cultivated under nutritious solution by omitting nutrients, observed the most limiting growth was reached when B and $\mathrm{N}$ were singly absent.

The $\mathrm{P}$ demand is generally higher in the initial phase of eucalyptus growth (FERNANDEZ et al., 2000). The availability of the element can directly influence on the response of nitrogen fertilization (MARSCHNER, 2012). Regarding leaves, Fernandez et al. (2000) have found the critical value of $1.4 \mathrm{~g} \mathrm{~kg}-1$ for both height and diameter. In clonal seedlings of E. urophylla x E. grandis, Rocha et al. (2013) obtained better quality by applying doses of 3.6 to $3.8 \mathrm{mg}$ plant-1 of $\mathrm{P}$ followed by a $30 \%$ increase in the plants survival in the field.

The prediction of $\mathrm{P}$ fertilization need in forest crops does not always consider other factors than the soil chemical attributes. As long as eucalyptus explore a significant volume of soil, it is possible that a mycorrhizae process followed by its recycling through the organic matter decomposition takes place on the root system (CAMPOS et al., 2011). Therefore, the foliar diagnosis shows itself as a useful tool to evaluate plants nutritional status. The expansion of forest cultivation to regions presenting soils naturally poor in boron-B, as in the case of Brazilian savannah, becomes responsible for the failure of reaching the maximum productivity capacity (SÃO JOSÉ et al., 2009). Sgarbi et al. (1999) highlighted B as one the most limiting nutrients for the growth of trees recently planted. According to the same authors, such application at the dose of $2.2 \mathrm{~kg}$ ha- 1 of $\mathrm{B}$ reduced 35 and $45 \%$ the incidence of dry pointer in a sandy and clayey soil, respectively.

Soils which received amendments are prone to present high content of calcium $(\mathrm{Ca})$ and magnesium $(\mathrm{Mg})$ and neutral $\mathrm{pH}$. It stimulates the increase of variable negative charges in the soil and leads to iron $(\mathrm{Fe})$ precipitation thus reducing the nutrient uptake (SOUZA et al., 2010). Leite et al. (2010) observed that height and diameters growth of stem for E. grandis and E. grandis $\mathrm{x} E$. urophylla were affected by the 30 days B suppression (41.4 and $37 \%$ in comparison to the control, respectively). Regarding the foliar application of micronutrients, Oliveira et al. (1999) did not observe response during the growth of Eucalyptus crop. However, low doses of B increased the dry mass production of E. citriodora (RAMOS et al., 2009). According to Mattiello et al. (2009), the influence of increasing $\mathrm{B}$ concentration in a nutritious solution depends on eucalyptus genetics.

Among the products that stimulate the development of plants are humic acids, seaweed, vitamins, amino acids and ascorbic acid (JARDIN, 2015). There are evidences of the effects of algae (Ecklonia maxima Osbeck) extracts used as bio-stimulant (SHARMA et al., 2014; STADEN et al., 2016) with a potential to contribute for the crops nutritional status in a sustainable way thus reducing the application of synthetical sources. Phenolic compounds such as eckol and phloroglucinaol were documented by Rengasamy et al. (2014) as effective biomolecules in the amelioration of plant propagation conditions. Staden et al. (2016) has documented that the biomolecules isolated from brown seaweed (Ecklonia maxima O.) can increase the growth of corn and bean roots. Halpern et al. (2015) in a review about biostimulants highlights the increased nutrient uptake, such as $\mathrm{Ca}, \mathrm{Mg}$ and $\mathrm{K}$ in species such as wheat and lettuce, due to the use of Ecklonia maxima. In general, even at low concentrations the seaweed extracts can induce physiological responses in plants, like improvement of flowering, growth and yield and also enhance the tolerance to abiotic stresses in several species (BATTACHARYYA et al., 2015). However, there are few studies that report the effect of biostimulants based on algae in the initial development of Eucalyptus. In the present study, it was aimed to evaluate the initial growth and nutritional status of hybrid plants of E. grandis $x$ E. urophylla (clone I144), submitted to the foliar application of boron, iron and bio-stimulant under $E$. maxima support and soil application of nitrogen and phosphorus doses.

\section{MATERIAL AND METHODS}

The experiment was carried out in a field belonging to the municipality of Tamarana, Parana $\left(23^{\circ} 35^{\prime}\right.$ 39" S, 51 $04^{\circ}$ ' 48" and $720 \mathrm{~m}$ a.s.l.). Prior to Eucalyptus Clone I144 planting (Oct-2013) the area was covered by 
degraded pasture (Paspalum notatum Flüegge), intended for grazing horses. The soil is characterized in Table 1. According to Köppen classification, the weather is Cfa, standing for subtropical humid with average, maximum and minimum annual temperatures of 18.6; 23.5 and $15.0^{\circ} \mathrm{C}$, respectively. It presents hot and raining summers and a few frosts during the winter season. The soil was classified as a Rhodic Hapludox, with $410 \mathrm{~g} \mathrm{~kg}^{-1}$ of clay (EMBRAPA, 2006).

Table 1. Soil chemical characterization.

\begin{tabular}{|c|c|c|c|}
\hline Attribute & Unit & $0-20 \mathrm{~cm}$ & $20-40 \mathrm{~cm}$ \\
\hline $\mathrm{pH} \mathrm{CaCl} 2$ & 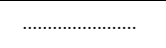 & 4.18 & 4.22 \\
\hline $\mathrm{pH} \mathrm{H} \mathrm{H}_{2} \mathrm{O}$ & $\ldots \ldots \ldots$ & 4.95 & 4.98 \\
\hline $\mathrm{H}+\mathrm{Al}^{3+}$ & $\mathrm{cmol}_{\mathrm{c}} \mathrm{dm}^{-3}$ & 4.78 & 4.41 \\
\hline $\mathrm{Al}^{3+}$ & $\mathrm{cmol}_{\mathrm{c}} \mathrm{dm}^{-3}$ & 1.09 & 1.09 \\
\hline $\mathrm{Ca}^{2+}$ & $\mathrm{cmol}_{\mathrm{c}} \mathrm{dm}^{-3}$ & 0.86 & 0.79 \\
\hline $\mathrm{Mg}^{2+}$ & $\mathrm{cmol}_{\mathrm{c}} \mathrm{dm}^{-3}$ & 0.42 & 0.31 \\
\hline $\mathrm{K}^{+}$ & $\mathrm{cmol}_{\mathrm{c}} \mathrm{dm}^{-3}$ & 0.09 & 0.05 \\
\hline CEC $\mathrm{pH}_{7,0}$ & $\mathrm{cmol}_{\mathrm{c}} \mathrm{dm}^{-3}$ & 6.16 & 5.56 \\
\hline $\mathrm{P}$ & $\mathrm{mg} \mathrm{dm}-3$ & 2.96 & 2.14 \\
\hline P-Rem & $\mathrm{mg} \mathrm{dm} \mathrm{m}^{-3}$ & 36 & 25.42 \\
\hline $\mathrm{SO}^{-2}{ }_{4}$ & $\mathrm{mg} \mathrm{dm^{-3 }}$ & $\mathrm{NaN}$ & 2.06 \\
\hline \multicolumn{4}{|c|}{$\begin{array}{l}\mathrm{pH} \text { in } \mathrm{CaCl}_{2} \text { and } \mathrm{H}_{2} \mathrm{O} \text { determined in a } 1: 2.5(v: v) \text { soil:solution } \\
\text { ratio. } \mathrm{H}+\mathrm{Al} \text { estimated by the } \mathrm{pH} \text { SMP method. } \mathrm{Al}^{3+}, \mathrm{Ca}^{2+} \\
\text { and } \mathrm{Mg}^{2+} \text { extracted with } \mathrm{KCl} 1 \text { mol } \mathrm{l}^{-1} \text { and determined by } \\
\text { spectrometry. } \mathrm{K}^{+} \text {and } \mathrm{P} \text { extracted with MEHLICH-1 and } \\
\text { determined by flame photometry and spectrometry, } \\
\text { respectively. } \mathrm{CEC}-\text { cation exchange capacity, estimated by } \\
\text { the sums of exchangeable cations. P-Rem }- \text { remaining } \\
\text { Phosphorus. } \mathrm{SO}^{-2} 4 \text { determined by turbidimetry. NaN - not } \\
\text { analyzed. }\end{array}$} \\
\hline
\end{tabular}

The soil field capacity was estimated according to equations described by Ruiz et al (2003). The real evapotranspiration exhibited a positive water surplus in all months except November. Thus distributed: 35.5 (oct); 18.8 (nov); 34.4 (dec.); 72.7 (jan); 105.1 (Feb); 65.5 (sea); 87.4 (apr) and $22 \mathrm{~mm}$ (may). The average temperatures and rainfall during the experimental period was presented in Fig. 1.

Regarding the amendments and fertilizers recommendation, it was randomly sampled 20 points at $0.0-0.10 ; 0.10-0.20 ; 0.20-0.30 ; 0.30-0.40$ and $0.40-0.50 \mathrm{~m}$ soil layers. $\mathrm{Ca}, \mathrm{Mg}$ and $\mathrm{K}$ contents were raised to 65,20 and $3 \%$ of $\mathrm{CEC}_{\mathrm{pH}} 7,00$ and phosphorus-P to $200 \%$ of its relative value (ALVAREZ et al., 2000) in the 0.0-0.20 m layer. Gypsum was applied aiming to provide $\mathrm{Ca}$ and neutralize aluminum on deeper layers. The products used to raise the mentioned soil chemical attributes were lime (38\% $\mathrm{CaO} ; 2 \% \mathrm{MgO})$, dolomitic lime (28\% CaO; $18 \%$ $\mathrm{MgO})$, potassium chloride $\left(58 \% \mathrm{~K}_{2} \mathrm{O}\right)$, reactive natural phosphate $\left(34 \% \quad \mathrm{P}_{2} \mathrm{O}_{5}\right.$ soluble in $2 \%$ citric acid) and gypsum (17\% Ca; $14 \% \mathrm{~S})$. All products have been applied in broadcast and incorporated until $0.2 \mathrm{~m}$ of depth.

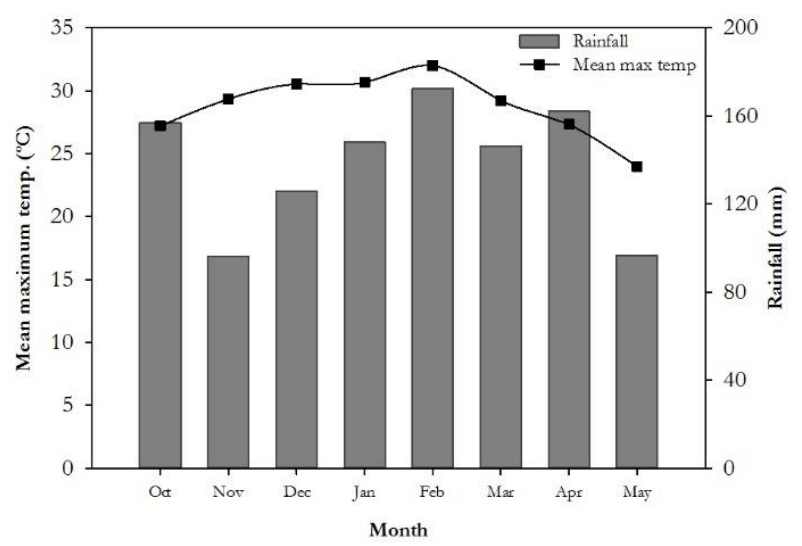

Figure 1. Average maximum temperatures and accumulated rainfall per month during the experimental period.

The ants control was performed by using formicide baits and the weeds control by means of manual "crowing" followed by pre-emerging herbicides application on the seedling crow and post-emerging application on between-lines of cultivation.

The experimental design was subdivided plots. The variable studied at the plot level was the fertilizers application and, at the subplot level, was the application of fertilizers doses via soil. The sources of foliar fertilizers contained boron (S1) - (10\% $\mathrm{p} \mathrm{v}^{-1}$ of B), S1+iron (S2) $\left(9 \% \mathrm{p} \mathrm{v}^{-1}\right.$ of $\left.\mathrm{Fe}\right), \mathrm{S} 1+\mathrm{S} 2+$ bio-stimulant $(\mathrm{S} 3)-(2.3 \% \mathrm{Mo}+$ $3.5 \% \mathrm{p} \mathrm{v}^{-1}$ of $\mathrm{Zn}$ ) in conjunction with algae (Ecklonia maxima) extract. The control had only water application. The support fertilization as composed by a control (no fertilizer application) and three doses of 10-20-00 fertilizer $(+0.3 \% \mathrm{Zn}, 0.2 \% \mathrm{~B}, 0.2 \% \mathrm{Cu}$ and $0.3 \% \mathrm{Mn})$ as 100,200 and $250 \mathrm{~g} \mathrm{plant}^{-1}$. It was used four replications $(\mathrm{n}=4)$ for each combined treatment making a total of 64 experimental units.

Each experimental plot had 16 plants, each one spaced in 3 by $3 \mathrm{~m}$ and distributed in four lines containing four plants each. The plants located in the center has been chosen to represent the useful representative for further analyses. It was evaluated the plants basal diameter and height at 45, 78, 117, 150 and 235 days after planting (DAP). Four pairs of leaves were collected at 235 DAP, located in the middle third of the plant (one in each quadrant), for the determination of $\mathrm{N}, \mathrm{P}, \mathrm{K}, \mathrm{S}, \mathrm{Ca}, \mathrm{Mg}, \mathrm{Cu}$, $\mathrm{Zn}, \mathrm{Mn}$ and Fe contents.

The height and the diameter of plants were measured by using a ruler and a pachymeter $(0.05 \mathrm{~m}$ from soil surface), respectively. The tissue samples were washed in tap water followed by deionized water. Nitrogen was 
analyzed through Kjeldahl micro distillation after sulfuric digestion. The other nutrients were digested via nitroperchloric acid digestion. Potassium-K was determined by flame photometer, sulfur-S by turbidimetry in a spectrophotometer at $420 \mathrm{~nm}$ and other nutrients by atomic absorption spectrometry.

Regarding the statistical analysis, the data were submitted to the tests of homoscedasticity and residues normality of Hartley and Shapiro-Wilk, respectively. After, the variance analysis (ANOVA) was performed and, in case of sufficiently low $P$-value of ANOVA's assumptions $(<0.05)$, the data were analyzed by Tukey method or by polynomial regression, depending on the nature of the data. The SISVAR program (FERREIRA, 2008) was used for the analyses, except for the Hartley test.

\section{RESULTS AND DISCUSSION}

The soil chemical analyzes revealed low base saturation and high aluminum saturation (Table 1). This condition is related to the history of low investment in correctives and fertilizers in the area, which may have limited plant development. However, it is possible to infer from Fig. 1 that the plants did not suffer with water deficit, except for the November month (IAPAR, 2017).

The soil fertilization did not interfere on the macronutrients concentration (Table 2). This result was expected for $\mathrm{K}, \mathrm{S}, \mathrm{Ca}$ and $\mathrm{Mg}$ due to the absence of such nutrients in the fertilizer applied at the subplot level, and due to the soil acidity correction, that was made with limestone in the same rate for the whole area. Also, we did not observe any interaction among the variables studied.

It was expected that increasing $\mathrm{N}$ rates via soil would lead to an increase in $\mathrm{N}$ uptake. However, there was an increase in $\mathrm{N}$ concentration only as a function of the applied foliar fertilizer, indicating that some of the nutrients applied were responsible for the increase of nutrient contents in tissues.

It is observed in Table 3 that the addition of $\mathrm{B}$ caused an increase in $\mathrm{S}$ concentration only, which may be related to the participation of $\mathrm{B}$ in the synthesis of nucleic acids and proteins and biomolecules containing $\mathrm{S}$. The nutrient that was related to the increase in $\mathrm{N}$ concentration in the eucalypt leaves was Fe (Figure 2), nutrient involved in the synthesis of heme and non-heme proteins found in chloroplasts, nitrate reduction and chlorophyll formation (N-containing biomolecules) - (JELALI et al., 2010). Iron$\mathrm{Fe}$ was also responsible for the increase in $\mathrm{K}$ and $\mathrm{Mg}$ contents. On the other hand, the bio-stimulant provided an increase in the concentrations of $\mathrm{K}$ and $\mathrm{Ca}$ in relation to the control (Table 3).
Table 2. $P$-value from ANOVA and coefficient of variation for $\mathrm{N}, \mathrm{K}, \mathrm{S}, \mathrm{Ca}$ and $\mathrm{Mg}$ contents as a function of the application of foliar products containing $\mathrm{B}, \mathrm{B}+\mathrm{Fe}$ and $\mathrm{B}+\mathrm{Fe}+$ Biostimulant (A), doses of $\mathrm{N}$ and $\mathrm{P}$ in the soil (B) and their interaction (A x B) at the eucalyptus clone I144.

\begin{tabular}{lccccc}
\hline $\begin{array}{l}\text { Cause of } \\
\text { variation }\end{array}$ & $\mathrm{N}$ & $\mathrm{K}$ & $\mathrm{S}$ & $\mathrm{Ca}$ & $\mathrm{Mg}$ \\
\hline & $\ldots \ldots \ldots \ldots \ldots \ldots \ldots \ldots \ldots \ldots \ldots \ldots \ldots \ldots \ldots \ldots \ldots \ldots \ldots \ldots \ldots \ldots \ldots \ldots \ldots \ldots \ldots \ldots \ldots \ldots \ldots \ldots \ldots \ldots \ldots \ldots \ldots \ldots \ldots$ \\
Foliar (A) & 0.02 & $<0.01$ & 0.01 & 0.35 & $<0.01$ \\
Soil (B) & 85.47 & 61.52 & 27.11 & 81.56 & 14.41 \\
A x B & 50.50 & 67.63 & 71.78 & 70.91 & 38.36 \\
CV (A) & 6.68 & 9.54 & 0.81 & 56.72 & 16.50 \\
CV (B) & 6.85 & 7.40 & 0.71 & 43.67 & 13.50 \\
\hline
\end{tabular}

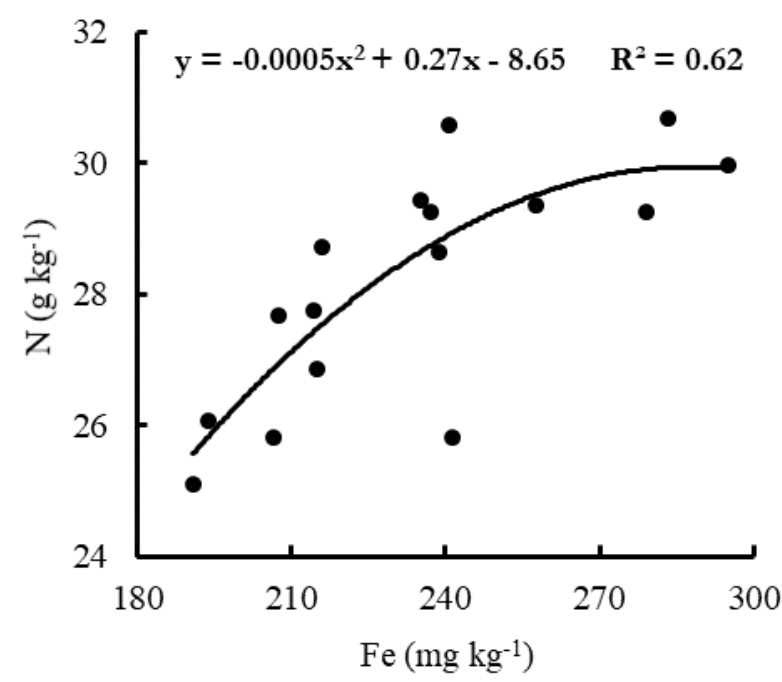

Figure 2. Iron and $\mathbf{N}$ relationship in leaves of the eucalyptus clone I144.

Graciano et al. (2006) observed that in most cases the concentration of $\mathrm{N}$ in the tissues decreases when the growth rate in plants fertilized with $\mathrm{N}$ increases at 44 DAP.

Changes in the concentration of nutrients can occur due to the increase of dry matter of plants, since it is known that they pass through cycles of concentration and dilution of nutrients, depending on the growth stages. The dry matter of the plants was not measured and, consequently, it was not possible to evaluate the effect of concentration/dilution of nutrients on the results obtained in Table 3. And even if they were made, would not solidly represent the effect of the treatments, as the plants continued to develop (Figure 3). However, according to the phytometric evaluations performed at the time of leaf collection at 235 days (Table 4), there were no differences in both growth and probably in the accumulation of dry 
matter of the plants, indicating that the differences found in Table 3 probably occurred due to the micronutrient leaf supply.

Table 3. Average values of macronutrients leaf contents as a function of the application of foliar products at the eucalyptus clone I144.

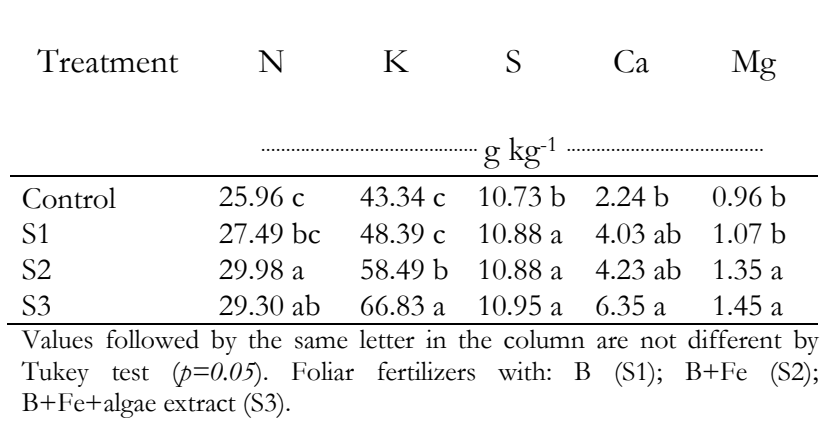

According to the data obtained by Wadt et al. (1998), the concentrations of N, K and S were above the optimal range, regardless of the treatment used. For Ca, only the control is below that range, whereas for $\mathrm{Mg}$, all treatments are below the optimum range. However, according to Higashi et al. (2000), K and S contents were high regardless of treatment, while others were dependent on the applied treatments. Nitrogen- $\mathrm{N}$ was between low and adequate levels, $\mathrm{Ca}$ between suitable and deficient and $\mathrm{Mg}$ between low and deficient. According to Carvalho et al. (2017) in Eucalyptus forests the rate of nutrients release from leaves followed the $\mathrm{K}>\mathrm{P}>\mathrm{N}$ order, which matches with the results of Abreu-Junior et al. (2017), that also reported $\mathrm{P}$ and $\mathrm{N}$ increases in Eucalyptus leafs during the initial growth of the specie.

The previous soil correction and homogeneity of the nutritional status of the plants were responsible for the absence of differences in their growth.

Potassium-K and $\mathrm{Ca}$ presented the greatest differences in quantitative and statistical terms. However, $\mathrm{K}$ is known to be excessively absorbed by the plants and, according to the authors mentioned above, in both cases the plants presented sufficient contents of the same.

Despite the differences in macronutrient concentrations, there was no effect on most of the studied phytometric attributes, except for stem diameter at 45 days as a function of foliar application (Table 4). This response may be related to the density and stomatal conductance, which are variable according to the plant age (SANTOS, et al., 2006). The plant height growth was higher than that observed by Magalhães (2013) for clone I144, in Vitória da Conquista, Bahia. They also presented superior growth in relation to data obtained by Cipriani et al. (2013) in Porto Velho, Rondônia.
Table 4. Summary of ANOVA with $p$-value and coefficient of variation for the phytometric characteristics evaluated as a function of the application of foliar products containing $B$, $\mathrm{B}+\mathrm{Fe}$ and $\mathrm{B}+\mathrm{Fe}+\mathrm{Bio}-$ stimulant $(\mathrm{A})$, doses of $\mathrm{N}$ and $\mathrm{P}$ in the soil (B) and their interaction (A $\times$ B) at the eucalyptus clone I144.

\begin{tabular}{|c|c|c|c|c|c|}
\hline \multirow{2}{*}{$\begin{array}{l}\text { Cause of } \\
\text { variation }\end{array}$} & \multicolumn{5}{|c|}{ DAP } \\
\hline & 45 & 78 & 117 & 150 & 235 \\
\hline & \multicolumn{5}{|c|}{ Height } \\
\hline Foliar (A) & 23.16 & 57.74 & 60.72 & 48.68 & 42.16 \\
\hline Soil (B) & 74.75 & 21.43 & 21.06 & 33.58 & 27.29 \\
\hline$A \times B$ & 82.08 & 45.81 & 35.47 & 62.19 & 72.96 \\
\hline $\mathrm{CV}(\mathrm{A})$ & 8.86 & 13.4 & 10.92 & 10.35 & 8.98 \\
\hline \multirow[t]{2}{*}{$\mathrm{CV}$ (B) } & 10.11 & 10.8 & 9.77 & 8.19 & 6.35 \\
\hline & \multicolumn{5}{|c|}{ Diameter } \\
\hline Foliar (A) & $0.74 *$ & 44.19 & 31.72 & 15.65 & 25.06 \\
\hline Soil (B) & 73.66 & 37.24 & 81.46 & 44.58 & 22.51 \\
\hline$A \times B$ & 60.83 & 48.01 & 65.02 & 59.28 & 28.67 \\
\hline $\mathrm{CV}(\mathrm{A})$ & 10.34 & 14.28 & 11.5 & 9.24 & 8.26 \\
\hline $\mathrm{CV}$ (B) & 12.17 & 10.45 & 10.77 & 8.59 & 6.55 \\
\hline
\end{tabular}

${ }^{*} p$-significant value.

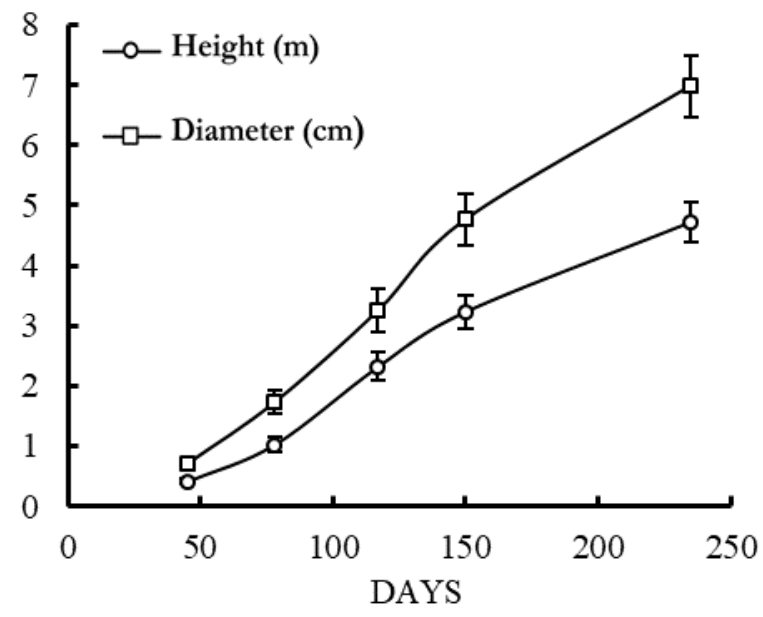

Figure 2. Growth in height and basal diameter of plants of the eucalyptus clone I144 as a function of time. Bars represent the mean standard deviation.

\section{CONCLUSIONS}

Under the conditions evaluated, fertilization with nitrogen and phosphorus via soil does not have any effect on the initial growth nor on the nutritional status of the eucalyptus clone I144. 
The application of boron, iron and bio-stimulant under Ecklonia maxima algae action, especially when combined, raises the levels of the macronutrients $\mathrm{N}, \mathrm{K}, \mathrm{Ca}$, $\mathrm{Mg}$ and $\mathrm{S}$, however, initial growth is not influenced.

\section{ACKNOWNLEGMENTS}

To the Coordination for the Improvement of Higher Level -or Education- Personnel for the financial support.

\section{REFERENCES}

ABREU JÚNIOR, C.H. et al. Fertilization using sewage sludge in unfertile tropical soils increased wood production in Eucalyptus plantations. Journal of Environmental Management, v. 203, p. 51-58, 2017.

ALVAREZ V., V. H.; NOVAIS, R. F.; DIAS, L. E.; OLIVEIRA, J. A. Determination and use of the remaining phosphorus. Information Bulletin of the Brazilian Society of Soil Science, v.25, p.21-32, 2000.

BATTACHARYYA, D.; BABGOHARI, M.Z.; RATHOR, P.; PRITHIVIRAJ, B. Seaweed extracts as biostimulants in horticulture. Scientia Horticulturae, v. 196, p. 39-48, 2015.

CAMPOS, D. T. S. et al. Mycorrhizal colonization in eucalyptus plantations. Revista Árvore, v. 35, n. 5, p. 965974, 2011.

CARVALHO, D.C.; et al. Ciclagem de nutrientes de um plantio de eucalipto em regeneração de espécies nativas no sub-bosque. Revista Floresta, v. 47, p. 17-27, 2017.

CIPRIANI, H. N.; VIEIRA, A. H.; GODINHO, V. P. C. Initial growth of Eucalyptus clones in Vilhena, RO. Research announcement $\mathrm{n}^{\circ} 388$, Brazilian Company of Agricultural Research (EMBRAPA), p. 3, 2013.

EMBRAPA - National Center for Soil Research. Brazilian system of soil classification. Rio de Janeiro: Embrapa Solos, 2 ed. 2006, 306 p.

FERNANDEZ, J. Q. P. et al. Productivity of Eucalyptus camaldulens affected by rate and placement of two phosphorus fertilizers to a Brazilian Oxisol. Forest Ecol, 127, p 93-102, 2000.

FERREIRA, D.F. SISVAR: a program for analysis and statistics teaching. Revista Symposium, v.6, p. 36-41, 2008.
GRACIANO, C. et al. Fertilization with phosphorus increase soil nitrogen absorption in young plants of Eucalyptus grandis. Forest Ecololy and Management, Amsterdam, v. 236, p. 202-210, 2006.

HALPERN, M. et al. The Use of Biostimulants for Enhancing Nutrient Uptake. In: SPARKS, D.L. (Ed.). Advances in Agronomy. Amsterdam: Elsevier, 2015, v. 130, p. 141-174.

HIGASHI, E. N.; SILVEIRA, R. L. V. A.; GONÇALVES, A. N. Nutritional monitoring in macro, mini and micro-clonal of Eucalyptus. In: GONÇALVES, J. L. M.; BENEDITTI, V. Nutrition and forest fertilization. Piracicaba: IPEF, 2000, p. 192-215.

IAPAR - INSTITUTO AGRONÔMICO DO PARANÁ. Agrometeorologia: dados diários. Disponível em: <http://www.iapar.br/modules/conteudo/conteudo.php? conteudo $=1828>$. Acesso em: 05 de maior de 2017 .

JARDIN, P. Plant biostimulants: Definition, concept, main categories and regulation. Scientia Horticulturae, v. 196, p. 3 14,2015

JELALI, N. et al. Physiological and biochemical responses for two cultivars of Pisum sativum ("Merveille de Kelvedon" and "Lincoln") to iron deficiency conditions. Scientia Horticulturae, v. 124, p. 116-121, 2010.

LEITE, S. M. M.; MARINO, C. L.; BONINE, C. Q. V. Responses of Eucalyptus grandis and E. grandis $\mathrm{x}$ E. urophylla clones to boron suppression. Scientia Florestalis, Piracicaba, v. 38, n. 85 , p. 19-25, 2010.

MAGALHÃES, G. C. Performaces of eucalyptus clones in the edaphic and climatic conditions of Vitória da Conquista, BA. 2013. 96 p. Dissertation (Master in Agronomy) - State University of South-west Bahia, Bahia, 2013.

MARSCHNER, H. Mineral nutrition of higher plants. $3^{\text {nd }}$ ed. San Diego: Academic Press, 2012. 651 p.

MATTIELLO, E. M. et al. Physiological characteristics and growth of eucalyptus clones in response to boron. Revista Arvore, v. 33, n. 5, p. 821-830, 2009.

OLIVEIRA, S. A.; MORAES, M. L. T.; BUZETTI, S. Effect of the application of NPK and micronutrients in the development of Eucalyptus citriodora Hook. Floresta, v. 29, n. 12, p. 27-36, 1999. 


\section{REVISTA SCIENTIA AGRARIA \\ Versão On-line ISSN 1983-2443 \\ Versão Impressa ISSN 1519-1125 \\ SA vol. 18 n $^{\circ} .4$ Curitiba Out/Dez 2017 p. 114-120}

PINTO, S. I. C. et al. Nutritional efficiency of eucalyptus clones in seedlings grown in nutrient solution. Revista Brasileira de Ciência do Solo, v. 35, p. 523-533, 2011.

RAMOS, S. J. et al. Growth and boron levels in eucalyptus plants (Eucalyptus citriodora) cultivated in two Oxisols under influence of boron doses and water availability. Revista Árvore, v. 33, n. 1, p. 57-65, 2009.

RENGASAMY, K. R. R. et al. Eckol - a new plant growth stimulant from the brown seaweed Ecklonia maxima. J. Appl. Phycol, v. 27, p. 581-587, 2014.

ROCHA, J. H. T. et al. Production and development of eucalyptus seedlings as a function of phosphorus doses. Cerne, v. 19, n. 4, p. 535-543, 2013.

RUIZ, H.A.; FERREIRA, G.B.; PEREIRA, J.B.M. Estimativa da capacidade de campo de Latossolos e Neossolos Quartzarênicos pela determinação do equivalente de umidade. Revista Brasileira de Ciência do Solo, v. 27 , p. 389-393, 2003.

SANTOS, L. D. T. et al. Characteristics of the eucalyptus leaf epidermis and its involvement with glyphosate tolerance. Planta Daninha, v. 24, n. 60, p. 513-520, 2006.
SÃO JOSÉ, J.; SILVA, I.; BARROS, N. Boron mobility in eucalyptus clones. Revista Brasileira de Ciência do Solo, v. 33, n. 6, 1733-1744, 2009.

SGARBI, F. et al. Growth and biomass production of Eucalyptus grandis $x$ Eucalyptus urophylla clone under conditions of macronutrient deficiency, B and Zn. Scientia Florestalis, Piracicaba, n. 56, p. 68-82, 1999.

SHARMA, H. S. S. et al. Plant biostimulants: a review on the processing of macroalgae and use of extracts for crop management to reduce abiotic and biotic stresses. Journal Appl. Phycol. 23, 465-490, 2014.

SOUZA, L. H. et al. Effect of rhizospheric and nonrhizospheric soil $\mathrm{pH}$ of soybean plants inoculated with Bradyrbizobium japonicum on the absorption of boron, copper, iron, manganese and zinc. Revista Brasileira de Ciência do Solo, v. 34, p. 1641-1652, 2010.

VAN STADEN, J.; RENGASAMY, K.R.R.; KULKARNI, M.G. Eckol - A biostimulant from Ecklonia. South African Journal of Botany, v. 103, p. 353, 2016.

WADT, P.G.S. et al. Reference values for macronutrients in eucalyptus obtained by DRIS methods and mathematical chance. Revista Brasileira de Ciência do Solo, v. 22, p. 685-692, 1998. 